\title{
Bazı Pamuk Çeşitlerinde iPBS Analiziyle Genetik Varyasyonun Ortaya Çıkarılması
}

\author{
Ahmet Metin Kumlay ${ }^{1}$, Barış Eren², Serap Demirel ${ }^{3}$, Fatih Demirel ${ }^{4 *}$, Bünyamin Yıldırım ${ }^{5}$ \\ 1 Iğdır Üniversitesi, Ziraat Fakültesi, Tarla Bitkileri Bölümü, Iğdır, Türkiye (ORCID: 0000-0001-9765-8674), akumlay@ hotmail.com \\ 2 Iğdır Üniversitesi, Ziraat Fakültesi, Tarımsal Biyoteknoloji Bölümü, Iğdır, Türkiye (ORCID: 0000-0002-3852-6476), bariseren86@ gmail.com \\ ${ }^{3}$ Van Yüzüncü Yıl Üniversitesi, Fen Fakültesi, Moleküler Biyoloji ve Genetik Bölümü, Van, Türkiye (ORCID: 0000-0002-3102-4924), serap_comart@ hotmail.com \\ 4* Iğdır Üniversitesi, Ziraat Fakültesi, Tarla Bitkileri Bölümü, Iğdır, Türkiye (ORCID: 0000-0002-6846-8422), drfdemirel@ gmail.com \\ 5 Iğdır Üniversitesi, Ziraat Fakültesi, Tarla Bitkileri Bölümü, Iğdır, Türkiye (ORCID: 0000-0003-2463-6989), byildirim71@ @mail.com
}

(İlk Geliş Tarihi 12 Ekim 2020 ve Kabul Tarihi 10 Ocak 2021)

(DOI: $10.31590 /$ ejosat.809479)

ATIF/REFERENCE: Kumlay, A. M., Eren, B., Demirel, S., Demirel, F. \& Yıldırım, B. (2021). Bazı Pamuk Çeşitlerinde iPBS Analiziyle Genetik Varyasyonun Ortaya Çıkarılması. Avrupa Bilim ve Teknoloji Dergisi, (21), 67-73.

$\ddot{O} \mathbf{z}$

Bu çalışmada, 10 adet pamuk (Gossypium hirsutum L.) çeşidinin moleküler karakterizasyonu yapılmıştır. DNA temelli 6 adet iPBS markörleri kullanılmış olup, toplamda 36 adet polimorfik bant görülmüş ve ortalama polimorfizm oranı $\% 77.65$ olarak saptanmıştır. Markörlerin ortalama polimorfizm değeri (PIC) de 0.27 , ortalama gen çeşitliliği (H) değerleri 0.34 , ortalama Dice benzerlik katsayı değeri 0.37 , korelasyon katsayı değeri (r) de 0.9026 olarak hesaplanmıştır. Genotipler arasındaki genetik ilişki, NTSYS-pc yazılımı kullanılarak belirlenmiş ve 0.0456 ile 0.8387 arasında değiştiği saptanmıştır. İlk üç eigen değerleri toplamı, toplam varyasyonun \%71.93'ünü açıklamıştır. Genotiplerin moleküler varyasyon gösterdiği belirlenmiş olup, genetik çeşitlilik sonuçlarının gelecekteki pamuk ıslah çalışmalarının planlanmasında kullanılabileceği sonucuna varılmıştır.

Anahtar Kelimeler: Gossypium hirsutum L., Polimorfizm, Islah, iPBS.

\section{Reveal of Genetic Variation by iPBS Analysis in Some Cotton Varieties}

\begin{abstract}
In current study, molecular characterization of 10 cotton (Gossypium hirsutum L.) varieties is performed. There are 6 DNA-based iPBS markers, a total of 36 polymorphic bands were detected and the mean of polymorphism rate was $77.65 \%$. The mean gene diversity $(\mathrm{H})$ of the markers was 0.34 and the mean polymorphism value (PIC) was 0.27 . The Dice similarity coefficient value and correlation coefficient was calculated as 0.337 and 0.9026 , respectively. Genetic diversity among cotton genotypes using NTSYS-pc software changed 0.0456 and 0.8387 . Sum of the first three Eigen value explained $71.93 \%$ of the total variation. The cotton genotypes used in this study showed highly molecular variation. It was concluded that results of genetic diversity could be used in the selection planning in future cotton breeding studies.
\end{abstract}

Keywords: Gossypium hirsutum L., polymorphism, breeding, iPBS.

\footnotetext{
*Sorumlu Yazar: drfdemirel@gmail.com
} 


\section{Giriş}

Pamuk (Gossypium sp.) dünya çapında önde gelen doğal lif ve biyoenerji (petrol, yağ) kaynağı olarak kabul edilmektedir. 2018 yılı için küresel bazda, 71 milyon ton pamuk üretimi ile 32.4 milyon hektarlık alanda seksenden fazla ülke tarafindan yetiştirilmiştir (FAOSTAT, 2018). Pamuk bitkisi, geniş kullanım alanı, istihdam olanakları ve oluşturduğu katma değer ile üretici ülkeler bakımından ekonomik değere sahip bir üründür.

Gossypium sp. 45 diploid $(2 \mathrm{n}=26)$ ve 5 allotetraploid $(2 \mathrm{n}=$ 52) olmak üzere, yaklaşık 50 türden oluşmaktadır. Bu türler genom yapılarına göre (A-G ve K) gruplandırılmaktadır (Fryxel, 1992). Allotetraploid türler A-genoma sahip Gossypium herbaceum L. veya G. arboreum L. $(2 \mathrm{n}=2 \mathrm{x}=26)$ ve D genoma sahip olan $G$. raimondii veya $G$. gossypioides $\mathrm{L}$. $(2 \mathrm{n}=2 \mathrm{x}=26)$ türelerinin melezlenmesi yoluyla oluşmuştur (Beasley, 1942; Wendel ve ark., 1992). Melezleme ile oluşan bu türler, $G$. barbadense L., G. darwinii Watt, G. hirsutum L., G. tomentosum ve G. mustelinum türlerini içerir (Percival ve ark., 1999; Wendel ve Crohn, 2003).

Sağladığı istihdam imkanlarından dolayı, pamuktan daha fazla yarar sağlanabilmesi için üstün ekonomik özelliklere sahip yeni çeşitlerin geliştirilmesi gerekmektedir. $\mathrm{Bu}$ nedenle pamuk yetiştiriciliğinin yapıldığı bölgelerde ıslah çalışmaları önem arzetmektedir. Bu amaçla, yüksek lif kalitesi ve bileşenlere sahip birçok stres ve hastalığa dayanıklı verimli pamuk çeşitlerinin geliştirilmesinde mevcut gen kaynaklarından yararlanmak kaçınılmazdır (Yu ve ark. 2012). Bitki genetik kaynakları; yerel çeşit ve popülasyonlar, kullanılmayan eski çeşitler, yabani akrabaları ve genetik özellikleri net olarak belirlenmemiş hatlardan oluşmaktadır (Tan, 1998). Özellikle yabani türlerin korunması, bitki 1slah çalışmaları için son derece önemlidir. Çünkü kalıtım materyallerinde bulunan genetik farklılık bitki sslahında çok önemli bir yere sahiptir.

Bu kapsamda 10 çeşit pamuk genotipinin genetik çeşitliliği iPBS moleküler markör yöntemi ile incelenmiştir. Bu çalışma ile elde edilen veriler ile planlanacak islah programlarına ve literatüre katkı sağlaması hedeflenmektedir.

\section{Materyal ve Metot}

Çalışmada on adet pamuk çeşiti (PG2018, CARISMA, BA151, BA440, FLASH, LYDIA, BA525, BA119, EDESSA ve BERKE) kullanılmıştır. Çeşitler moleküler karakterizasyon çalışmaları için Erciyes Üniversitesi Genom ve Kök Hücre Merkezi Tarımsal Biyoteknoloji Birimine ait moleküler genetik laboratuvarında viyollerde çimlendirilip DNA izolasyonu yapılmıştır. DNA ekstasyonu için Doyle ve Doyle (1990)'e göre yapılan CTAB protokolü modifiye edilerek uygulanmıştır. İzole edilen DNA'ların miktarları $230 / 280 \mathrm{~nm}$ dalga boyunda BioSpec-nano Shimadzu Biotech spektrofotometrik cihazı kullanılarak ölçülmüştür. Miktarı ölçülen DNA'lar PCR analizi için $5 \mathrm{ng} / \mu \mathrm{l}$ olacak şekilde hazırlanmıştır. IPBS-retrotranspozons Polimeraz Zincir Reaksiyonu (PCR) bileşenleri $9 \mu \mathrm{l}$ dH2O, $2 \mu \mathrm{l}$ primer, $2 \mu \mathrm{l}$ 10X PZR buffer, $2 \mu \mathrm{l} \mathrm{MgCl} 2,0.5 \mu \mathrm{l}$ dNTP, $0.5 \mu \mathrm{l}$ Taq DNA polymerase ve $4 \mu$ DNA olmak üzere toplam hacim $20 \mu$ olacak şekilde hazırlanmıştır. PCR işleminde reaksiyon için $95{ }^{\circ} \mathrm{C}$ 'de 1 dakika 1 döngü, $95{ }^{\circ} \mathrm{C}$ 'de 45 saniye markör bağlanma sıcaklığında 45 saniye $72^{\circ} \mathrm{C}$ 'de 1 dakika 42 döngüyle yapıldıktan sonra $72{ }^{\circ} \mathrm{C}$ 'de 5 dakika 1 döngü basamakları ile sonlandırılmıştır. PCR işlemi sonrasında çoğaltılan DNA'lar TBE tampon içerisinde \%2'lik agaroz jel üzerinde elektroforez kullanılarak 120 V'da 3 saat yürütülmüştür. Elektroforez işleminde kuyulara PCR ürünü, $2 \mu$ yükleme boyası ve 100 3000 bç'lik 100 bp DNA Ladder H3 RTU (GeneDirex) eklenmiştir. Elektroforez işlemi sonunda jeller UV 1şını altında fotoğrafları çekilip kayıt edilmiştir.

DNA'lar iPBS markörleri kullanılarak çoğaltılmıştır (Kalendar ve ark., 2010). Görüntüler incelenerek bant profilleri (bant varlığında “1”, bant yokluğunda “0”) kodlanmıştır. Kullanılan markörlere ait $\mathrm{H}$ (gen çeşitliliği) değerleri ve PIC (polimorfizm bilgi içeriği) değeri PowerMarker V3.25 programı kullanılarak hesaplanmıştır (Liu ve Muse, 2005). Genotipler arasındaki benzerlik katsayıları hesaplanarak (Dice, 1945) UPGMA (Aritmetik Ortalamayı Kullanan Ağırlıksız Çift Grup Metodu) metodu ve Neighbor Joining (NJ) metodu ile dendogramlar NTSYS-pc V2.11 programı kullanılarak oluşturulmuştur. Ayrıca, Eigen vektörü hesaplanarak iki boyutlu (2D) ve üç boyutlu (3D) grafikler elde edilmiştir (Rohlf, 2000).

\section{Araştırma Sonuçları ve Tartışma}

Yaptığımız çalışmaya göre, en az polimorfik bant sayısı IPBS-2087 ve IPBS -2390 markörlerine ait olup, en fazla bant sayısı IPBS-2222 isimli markördür. Toplam bant sayısı 46 ve polimorfik bant sayısı 36 olarak tespit edilmiştir. Markör başına ortalama polimorfik bant sayısı 7.66 olarak hesaplanmıştır (Tablo 1). Noormohammadi ve ark. (2013), İran'da pamuk çeşitlerinde ve islah hatlarında genetik çeşitliliği ortaya koymak için 17 RAPD, 18 ISSR ve 4 SSR markörünü kullanmışlardır. Çalışmada test edilen RAPD markörlerinden ortlama polimorfizim oranını $\% 25.8$ olarak, ISSR markörlerinden ortlama polimorfizim oranını $\% 50.4$ olarak, SSR markörlerinden ortlama polimorfizim oranını $\% 57$ olarak hesaplamışlardır. Bizim çalışmamızın ortalama polimorfizm oranı \%77.65 olup, polimorfizm oranı Noormohammadi ve ark. (2013)'nın çalışmalarından yüksektir. 
Tablo 1. iPBS markörlerinin karakterizasyon bilgileri

\begin{tabular}{|c|c|c|c|c|c|c|c|}
\hline \multirow[b]{2}{*}{ Markör İsmi } & \multirow[b]{2}{*}{$\begin{array}{c}\text { Markör Sekansları } \\
\text { 5'--3, }\end{array}$} & \multirow[b]{2}{*}{$\begin{array}{c}\text { Sicaklık } \\
\left({ }^{\circ} \mathbf{C}\right)\end{array}$} & \multicolumn{2}{|c|}{ Bant Bilgileri } & \multicolumn{3}{|c|}{ Çeşitlilik Değerleri } \\
\hline & & & Toplam Bant & Polimorfik Bant & $\mathbf{P \%}$ & $\mathbf{H}$ & PIC \\
\hline IPBS -2087 & GCAATGGAACCA & 57 & 6 & 4 & 66.66 & 0.32 & 0.26 \\
\hline IPBS -2298 & AGAAGAGCTCTGATACCA & 60 & 8 & 6 & 75 & 0.48 & 0.36 \\
\hline IPBS -2390 & GCAACAACCCCA & 57.5 & 5 & 4 & 80 & 0.35 & 0.28 \\
\hline IPBS -2222 & ACTTGGATGCCGATACCA & 55 & 11 & 10 & 90.9 & 0.27 & 0.23 \\
\hline IPBS -2278 & GCTCATGATACCA & 47 & 10 & 7 & 70 & 0.38 & 0.30 \\
\hline IPBS -2388 & TTGGAAGACCCA & 50 & 6 & 5 & 83.33 & 0.26 & 0.22 \\
\hline \multicolumn{3}{|l|}{ Toplam } & 46 & 36 & & & \\
\hline \multicolumn{3}{|l|}{ Ortalama } & 7.66 & 6 & 77.65 & 0.34 & 0.27 \\
\hline
\end{tabular}

P\%: Yüzdelik polimorfizm, H: Gen çeşitliliği, PIC: Polimorfizm bilgi içeriği

Çalışmamızda en düşük $H$ değeri 0.26 olup en yüksek $H$ değeri 0.48 olarak belirlenmiştir. Ortalama H değeri 0.34 olarak hesaplanmıştır. En düşük PIC değeri 0.22 olup en yüksek 0.36 olarak saptanmıştır. Ortalama PIC değeri 0.27 olarak belirlenmiştir (Tablo 1). Noormohammadi ve ark. (2013), tarafından RAPD moleküler markörlerini kullanarak ortalama PIC değerini 0.19 ve ortalama $\mathrm{H}$ değerini 0.114 olarak bulmuşlardır. ISSR moleküler markörlerini kullanarak ortalama PIC değerini 0.321 ve ortalama $\mathrm{H}$ değerini 0.223 olarak bildirmişlerdir. SSR moleküler markörlerini kullanarak ortalama PIC değerini 0.353 ve ortalama $\mathrm{H}$ değerini 0.154 olarak hesaplamışlardır. Ashraf ve ark. (2016) 30 pamuk genotipinde ISSR markörü kullanarak elde ettikleri PIC değerini 0.064 ile 0.492 arasında değiştiğini bildirmişlerdir. Mevcut çalışmalar ile tutarlı sonuçların sergilendiği görülmektedir.

$\mathrm{Bu}$ çalışmamızın sonucunda DICE benzerlik katsayı değeri ortalama 0.37 olarak belirlenmiştir. Benzerlik katsayı değerlerine göre BA525 ile BA119 isimli genotipler 0.0456 değeri ile birbirine en az benzerlik gösteren, BERKE ve BA119 isimli genotipler 0.8387 benzerlik katsayı değeri en çok benzerlik gösteren genotipler olarak tespit edilmiştir (Tablo 2).

Tablo 2. IPBS bantlarına göre DICE benzerlik katsayı değerleri

\begin{tabular}{|c|c|c|c|c|c|c|c|c|c|c|}
\hline & PG2018 & CARISMA & BA151 & BA440 & FLASH & LYDIA & BA525 & BA119 & EDESSA & BERKE \\
\hline PG2018 & 1 & & & & & & & & & \\
\hline CARISMA & 0.2500 & 1 & & & & & & & & \\
\hline BA151 & 0.6923 & 0.4000 & 1 & & & & & & & \\
\hline BA440 & 0.3448 & 0.3200 & 0.3810 & 1 & & & & & & \\
\hline FLASH & 0.3158 & 0.2667 & 0.4706 & 0.3000 & 1 & & & & & \\
\hline LYDIA & 0.1000 & 0.2857 & 0.4444 & 0.1333 & 0.3636 & 1 & & & & \\
\hline BA525 & 0.0983 & 0.0521 & 0.0846 & 0.0654 & 0.1248 & 0.5714 & 1 & & & \\
\hline BA119 & 0.6250 & 0.4286 & 0.6923 & 0.6061 & 0.2609 & 0.1000 & 0.0456 & 1 & & \\
\hline EDESSA & 0.3846 & 0.5455 & 0.3810 & 0.5926 & 0.3529 & 0.1333 & 0.1245 & 0.5333 & 1 & \\
\hline BERKE & 0.7407 & 0.3478 & 0.8182 & 0.5714 & 0.3333 & 0.1250 & 0.0741 & 0.8387 & 0.4800 & 1 \\
\hline
\end{tabular}

Çalışmamızda elde edilen dendogramdan ultrametrik benzerlik değerleri oluşturulmuş olup, DICE benzerlik değerleri ile Mantel testi gerçekleştirilmiştir. Analizin sonucuna göre 10 pamuk genotipine ait $\mathrm{r}=0.9026$ (korelasyon katsayı değeri) olarak saptanmıştır. Korelasyon değerinin 0.9 veya 0.9 'dan büyük olması dendrogram ile benzerlik değerleri arasında yüksek korelasyon oluşturduğunu ve dendrogramın benzerlik değerlerini iyi temsil ettiği bildirilmektedir (Mohammadi ve Prasanna, 2003).

UPGMA dendogramı (Şekil 1) incelediğinde, genotipleri ilk başta iki ana kümeye ayırmıştır (A ve B). A kümesinde BA525 e-ISSN: 2148-2683 ve LYDIA isimli genotipler kendi aralarında grup oluşturmuşlardır. İki boyutlu temel bileşen analizinde de bu iki genotip diğerlerinden ayrılmıştır (Şekil 3). Bu iki genotip her ne kadar diğer genotiplerden ayrılsada üç boyutlu grafikte ise birbirinden farklı noktalarda yer aldıkları görülmüştür (Şekil 4). $\mathrm{B}$ ana küme altında alt kümeler oluşmuştur (C ve $\mathrm{D})$. C kümesinde sadece FLASH isimli genotip yer almıştır. D alt kümesinde ise iki yeni alt küme meydana gelmiştir (E ve F). E kümeside sadece CARISMA isimli genotip yer almıştır. F kümesi de kendi içerisisinde iki alt katagoriye ayrılmıştır (F1 ve F2). F1 kümesini oluşturan EDESSA ve BA440 isimli genotipler 
iki boyutlu ve üç boyutlu temel bileşenler grafiğinde de aynı kümeye ait olduklarını göstermişlerdir. F2 kümesini oluşturan BERKE, BA119, BA151 ve PG2018 isimli genotiplerde iki boyutlu ve üç boyutlu temel bileşenler grafiğinde aynı kümeye ait oldukları görülmüştür.

NJ dendogramında (Şekil 2), genotipler ilk olarak iki ana kümeye bölünmüştür (1 ve 2). Sonrasında, 1 numaralı küme iki alt kümeye bölünmüştür (3 ve 4). 3 numaralı kümeyi BA440 isimli genotip oluşturmuştur. 4 numaralı küme 5 ve 6 numaralı alt kümelere ayrılmıştır. 6 numaralı kümeyi oluşturan EDESSA ve CARISMA isimli genotipler UPGMA dendogramından farkl1 olarak kendi aralarında küme oluşturmuş olup, iki ve üç boyutlu dendogramda da birbirine daha yakın oldukları belirlenmiştir. NJ dendogramının 6 numaralı kümeyi, temel bileşenler grafiğiyle benzer sonuç verdiği saptanmıştır. 5 numaralı grup kendi içerisinde iki alt kümeye ayrılmıştır (7 ve 8). FLASH isimli genotip 8 numaralı kümeyi oluştururken, BA525 ve LYDIA isimli genotipler 7 numaralı kümeyi oluşturmuştur. Temel bileşen analizinde de bu genotipler diğer genotiplerden oldukça farlı noktalarda yer aldığı belirlenmiştir. 2 numaralı ana küme kendi içerisinde iki alt kümeye ayrılmıştır (9 ve 10). 2 numaralı ana kümenin UPGMA dendogramı ile benzerlik gösterdiği saptanmıştır. BA119 ve BERKE isimli genotipler 9 numaralı kümeyi oluştururken, PG2018 ve BA151 isimli genotipler 10 numaralı kümeyi oluşturmuşlardır.

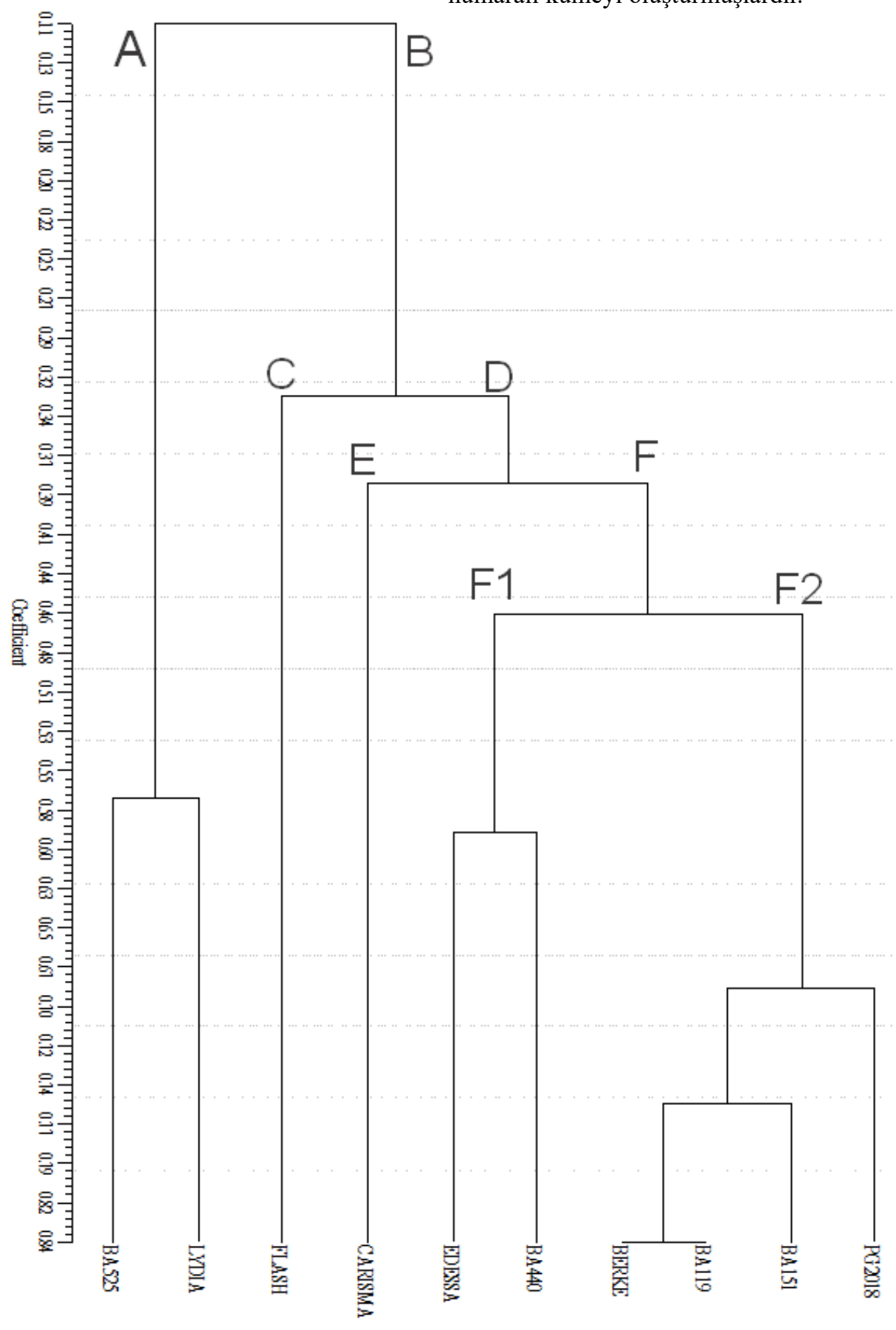

Şekil 1. Benzerlik değerleriden yararlanılarak oluşturulan UPGMA dendogramı 
European Journal of Science and Technology

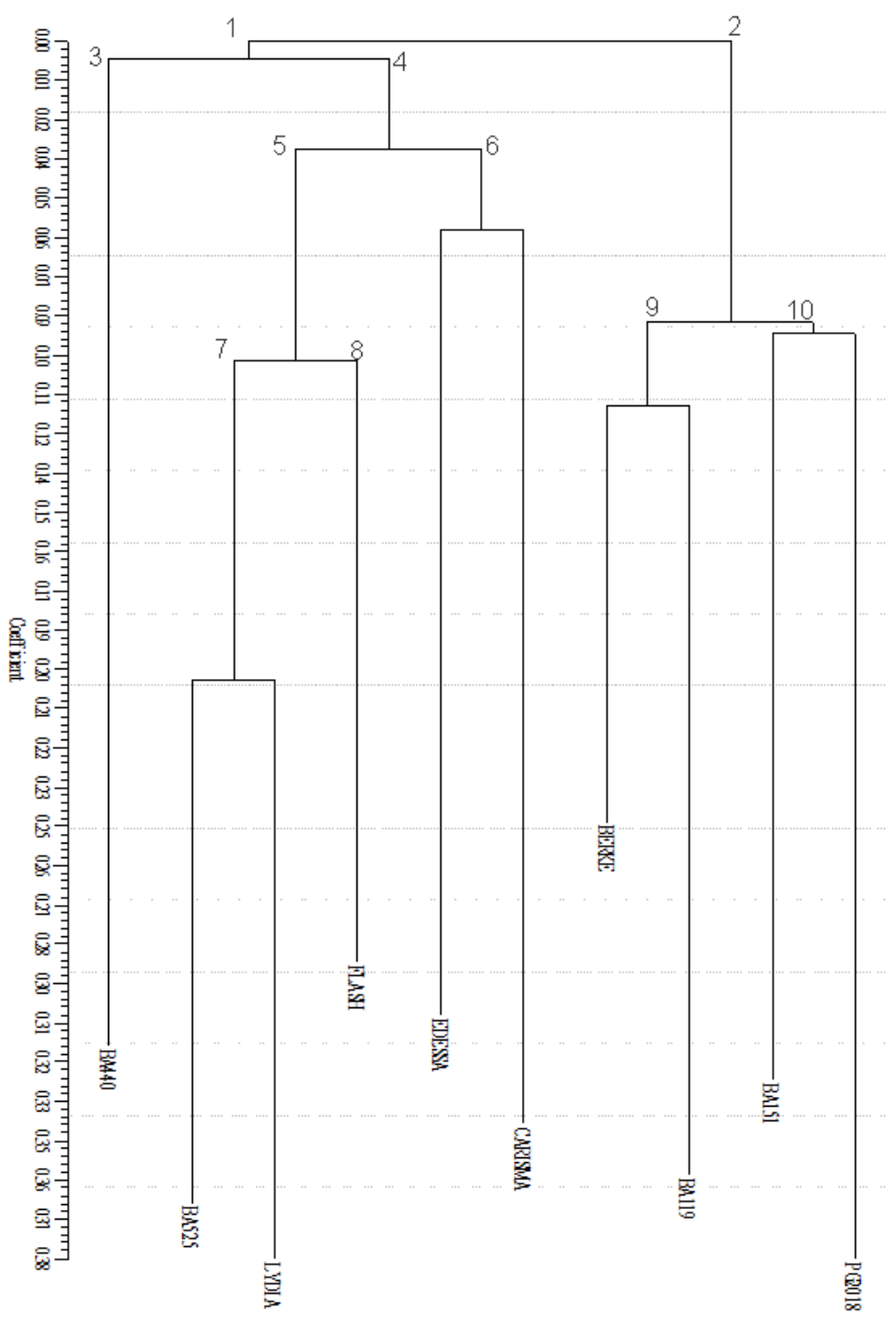

Şekil 2. 10 pamuk genotipi için NJ dendogramı

10 pamuk genotipi arasındaki genotipik farklılığı göstermek için PCA yapılmıştır. PCA sonucunda 2D ve 3D grafikler elde edilmiştir. PCA popülasyonların genetik olarak ilişkilerini 2D veya 3D mekanlarda görsel grafik olușturmada kullanılmaktadır (Klaedtke ve ark., 2017).

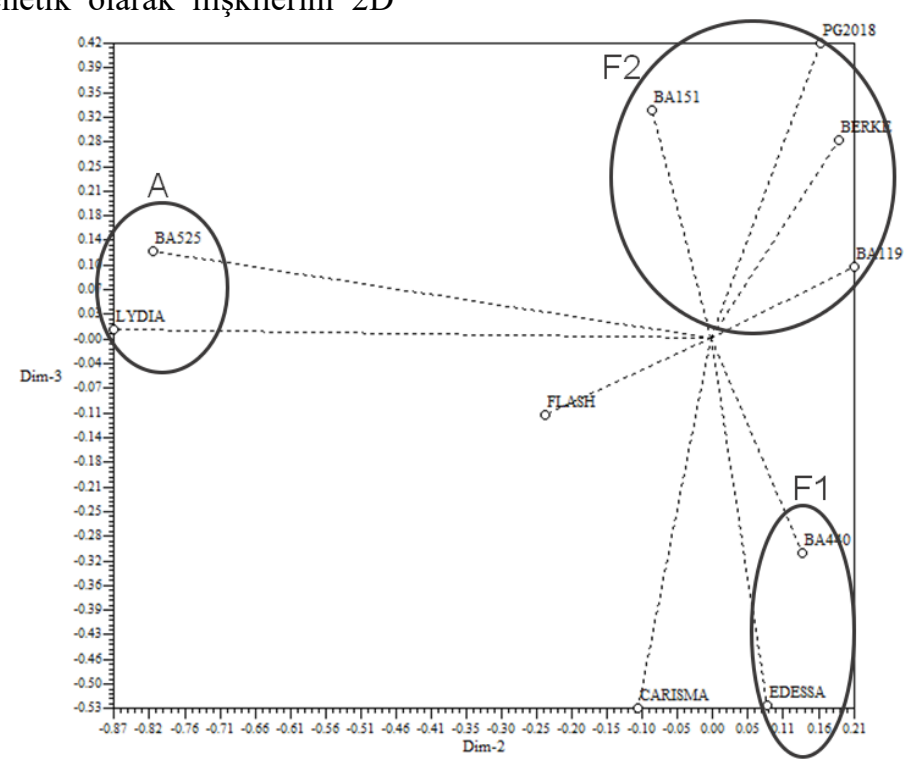

Şekil 3. IPBS verileriyle elde edilen $2 D$ grafik 


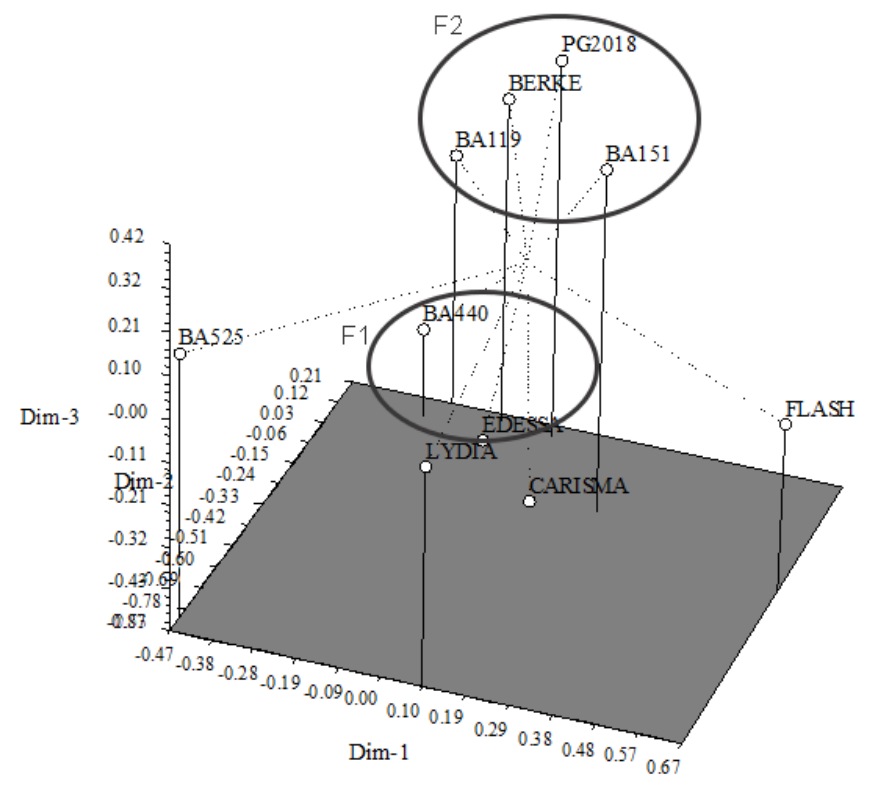

Şekil 4. IPBS verileriyle elde edilen $3 D$ grafik

PCA ile elde edilen dendogramlar ve grafikler incelendiğinde birbiri arasında tutarlı sonuçlar tespit edilmiștir. Benzerlik değerleri kullanılarak elde edilen PCA sonucunda 2D ve 3D grafiklerin ilk üç anabileșenin değerleri toplamına göre toplam varyasyonun \%71.93'ünü açıkladığı saptanmıştır (Tablo $3)$.

Tablo 3. İlk üç anabileşene göre Eigen değerleri

\begin{tabular}{cccc}
\hline Bileşenler & Eigen Değeri & Yüzdeleri & Eklemeli Toplamları \\
\hline 1. & 4.52 & 45.21 & 45.21 \\
\hline 2. & 1.61 & 16.11 & 61.32 \\
\hline 3. & 1.06 & 10.61 & 71.93 \\
\hline
\end{tabular}

\section{Sonuç}

$\mathrm{Bu}$ çalışma çerçevesinde ticari olarak tescilli 10 pamuk çeşidi 6 IPBS markörleriyle incelenmiştir. Elde edilen veriler NTSYS ve POWERMARKER programları ile analiz edilmiştir. Markörlere ait karakterizasyon değerleri hesaplanmıştır. Pamuk genotiplerinin DICE benzerlik değerleri, iki ve üç boyutlu temel bileşenler grafiğgi, UPGMA ve NJ dendogramları belirlenmiştir. Son olarakta, temel bileşenler analizine ait Eigen değerleri hesaplanmıştır.

Çalışmamızda 6 IPBS markörlerü pamukta DNA bölgelerini çoğalttığ 1 saptanmıştır. $\mathrm{Bu}$ markörler toplamda 46 bantın 36'sında polimorfizm oluşturmuş ve ortalama \%77.65 polimorfizm yüzdesi belirlenmiştir. Ortalama $H$ değerlerini 0.34 , ortalama PIC değerini 0.27 ve DICE benzerlik katsayı değerini 0.37 olarak tespit edilmiştir. Korelasyon katsayı değeri ise (r) de 0.9026 olarak saptanmıştır. BA525 isimli genotip ile BA119 isimli genotip 0.0456 benzerlik katsayı değeri ile birbirine en uzak, BERKE ve BA119 isimli genotipler 0.8387 benzerlik katsayı değeri ile en yakın ilişki gösteren genotipler olarak belirlenmiştir.
BA525 ile BA119 isimli genotipler DICE benzerlik indeksinden yararlanılarak oluşturulan UPGMA ve NJ dendogramları üzerinde birbirlerinden farklı kümelerde yer aldıkları belirlenmiştir (Şekil 1 ve Şekil 2). Bu iki genotip ıslah çalışmalarında amaca yönelik kullanılabileceği kabul edilebilir. Fakat, farklı moleküler ve morfolojik çalışmalar ile bu iki genotipin incelenmesi devam etmelidir.

Sonuç olarak, ıslah programlarında kullanılan pamuk genotiplerinin moleküler varyasyonu göz önüne alınarak IPBS markörlerinin filogenetik çalışmalarında etkili bir şekilde kullanılabileceği, bu sonuçların genetik ve ıslah çalışmalarına katkı sağlayabileceği kanaatine varılmıştır.

\section{Teşekkür}

Bu araştırma Iğdır Üniversitesi Bilimsel Araştırma Projeleri Koordinatörlüğünün desteği ile (2018-FBE-A05) gerçekleştirilmiştir. Desteklerinden dolayı teşekkür ederiz. 


\section{Kaynakça}

Ashraf, J., Malik, W., Iqbal, M. Z., ALI, K. A., Qayyum, A., Noor, E., ... \& Ahmad, M. Q. (2016). Comparative analysis of genetic diversity among bt cotton genotypes using est-ssr, issr and morphological markers. Journal Of Agricultural Science And Technology. 18(2) 517-531.

FAOSTAT, 2018. http://www.fao.org/faostat/en/\#home. (Erişim tarihi: 04/10/2020).

Fryxell, P.A., (1992). A Revised Taxonomic Interpretation of Gossypium L. (Malvaceae). Rheedea, 2, 108-165.

Beasley, J. O. (1942). Meiotic chromosome behavior in species, species hybrids, haploids, and induced polyploids of Gossypium. Genetics, 27(1), 25.

Dice, L.R., (1945). Measures of The Amount of Ecologic Association Between Species. Ecology, 26, 297-302.

Doyle, J.J., Doyle, J.E., (1990). Isolation of Plant DNA From Fresh Plant Tissue. Focus, 12,13-15.

Kalendar, R., Antonius, K., Smýkal, P. \& Schulman, A.H., (2010). IPBS: A Universal Method for DNA Fingerprinting and Retrotransposon Isolation. Theoretical and Applied Genetics, 121(8), 1419-1430.

Klaedtke, S.M., Caproni, L., Klauck, J., de la Grandville, P., Dutartre, M., Stassart, P.M., Chable, V., Negri, V. \& Raggi, L., (2017). Short-Term Local Adaptation of Historical Common Bean (Phaseolus vulgaris L.) Varieties And İmplications for In Situ Management of Bean Diversity. International Journal of Molecular Sciences, 18(3), 493.

Liu, K., \& Muse, S. V. (2005). PowerMarker: an integrated analysis environment for genetic marker analysis. Bioinformatics, 21(9), 2128-2129.
Mohammadi, S.A. \& Prasanna, B.M., (2003). Analysis of Genetic Diversity in Crop Plants Salient Statistical Tools and Considerations. Crop Science, 43(4), 1235-1248.

Noormohammadi, Z., Hasheminejad-Ahangarani, Y. F., Sheidai, M., Ghasemzadeh-Baraki, S., \& Alishah, O. (2013). Genetic diversity analysis in Opal cotton hybrids based on SSR, ISSR, and RAPD markers. Genetics and molecular research: GMR, 12(1), 256-269.

Percival ,A.E., Wendel, J.F. \& Stewart, J.M., (1999). Taxonomy and germplasm resources. In: Smith CW, Cothren JT, editors. Cotton: Origin, History, Technology, and Production. New York, NY, USA: John Wiley and Sons Inc., pp. 33-63.

Rohlf, J.F., (2000). NTSYS-pc: Numerical Taxonomy and Multivariate Analysis System. Exeter Software, Setauket, New York.

Tan, A. (1998). Current status of plant genetic resources conservation in Turkey. In International Symposium on In Situ Conservation of Plant Genetic Diversity, Antalya (Turkey), 4-8 Nov 1996. Central Research Institute for Field Crops.

Wendel, J. F., Brubaker, C. L., \& Percival, A. E. (1992). Genetic diversity in Gossypium hirsutum and the origin of upland cotton. American Journal of Botany, 79(11), 1291-1310.

Wendel, J.F., Crohn, R.C., (2003). Polyploidy and the evolutionary history of cotton. Advances in Agronomy 78: 139-186.

Yu, J.Z., Fang, D.D., Kohel, R.J., Ulloa, M., Hinze, L.L., Percy, R.G., Zhang, J., Chee, P., Scheffler, B.E. \& Jones, D.C., (2012). Development of core set of SSR markers for the characterization of Gossypium germplasm. Euphytica. 187(2), 203-213. 